\title{
Mølletvangens ophævelse i hertugdømmet Slesvig
}

\author{
Af Thomas Clausen
}

I århundreder havde indbyggerne i hertugdømmet Slesvig været underlagt mølletvang. Efter Treårskrigen afsluttedes imidlertid mølletvangens epoke i Sønderjylland ved et lovindgreb. Reformen blev dog ikke gennemført uden at møde modstand fra møllernes rækker. I artiklen tegner forfatteren hovedlinjerne i begivenhedsforløbet omkring mølletvangens afskaffelse. Synsvinklen er de tidligere tvangsmølleres ${ }^{1}$.

\section{Indledning}

Ved en provisorisk forordning af 21. november 1852 blev mølletvangen afskaffet i hele hertugdømmet Slesvig. ${ }^{2}$ Gældende fra det følgende årsskifte skulle det i princippet stå enhver indbygger i hertugdømmet frit for at benytte, hvilken mølle han måtte ønske til formaling af sit førhen tvangspligtige ${ }^{3}$ korn. De arbejdspræstationer, som beboerne i et tvangsdistrikt - det til møllen bundne opland - tidligere skulle yde til møllen, blev ligeledes fjernet. Det betød dog ikke, at møllenæringen var fuldkommen frigivet. Reglen om, at ingen ny mølle kunne anlægges uden kongelig koncession (tilladelse), opretholdtes. Desuden var den enkelte møllers malerettigheder ofte indskrænkede som følge af den udstedte koncessions nærmere bestemmelser, således at der f.eks. kun måtte forarbejdes bestemte kornsorter på møllen eller alene males til eksport. ${ }^{4}$ Ophævelsen af mølletvangen liberaliserede mølleforholdene uden at virke revolutionerende.

Mølletvangens afvikling i hertugdømmet Slesvig har ikke tidligere været behandlet i forskningslitteraturen. Afskaffelsen af mølletvangen havde ikke desto mindre vidtrækkende følger for såvel møllegæster som for indehavere af de tidligere tvangsmøller. I denne artikel vil hovedfokus ligge på sidstnævnte gruppe. Hvordan stillede møllerne sig til tvangsmølleriets ophør? I hvilken udstrækning blev møllernes interesser tilgodeset i procesforløbet ved mølletvangens afskaffelse? Det er nogle af de spørgsmål, der vil blive belyst. Artiklen giver 
desuden et nærmere indblik i 1850'ernes lovgivnings- og administrationspraksis i den danske helstat eksemplificeret ved loven om mølletvangens ophævelse. Kilderne til undersøgelsen er fortrinsvis arkivmateriale fra Ministeriet for Hertugdømmet Slesvig. ${ }^{5}$ Det drejer sig især om rapporter udfærdiget i forbindelse med taksationer af de forhenværende tvangsmøller i hertugdømmet, korrespondance mellem lokaløvrigheden og Ministeriet for Hertugdømmet Slesvig samt henvendelser fra de tidligere tvangsmølleindehavere til ministeriet. Desuden er der anvendt trykt kildemateriale i form af tidender fra den slesvigske stænderforsamling og helstatens rigsråd. Studiet omfatter hele hertugdømmet Slesvig, dog med særlig vægt på det nordslesvigske område. Personnavne på de forskellige tvangsmøllere, som optræder i artiklen, er, med en enkelt undtagelse, for overskuelighedens skyld alene angivet under kildehenvisningerne i tekstens fodnoter.

\section{Forordningen om mølletvangens afskaffelse}

Der var overordnet set tre grunde til, at regeringen besluttede at afskaffe mølletvangen ved lov i begyndelsen af 1850 'erne. ${ }^{6}$ For det første havde styret siden midten af 1830'erne oplevet et stigende folkeligt pres for at få mølletvangen afviklet. Forsøg på en administrativ og gradvis afskaffelse havde ikke givet tilfredsstillende resultater. For det andet nødvendiggjorde den industrielle udvikling og tendensen til faldende kornpriser på verdensmarkedet en højere grad af forarbejdning i produktionen, hvilket krævede et opgør med de skranker, mølletvangen opsatte på eksportvirksomhed.7 For det tredje kom mølletvangen, da man efter Treårskrigen harmoniserede told- og skattelovgivningen i det danske monarki, til at fremstå som en uretfærdig begrænsning på en række branchers erhvervsmæssige udfoldelsesmuligheder i hertugdømmerne, ${ }^{8}$ idet mølletvangen ikke fandtes i kongeriget, eller i hvert fald var et særsyn. Navnlig brændevinsbrænderiafgiftens indførelse i landsdelene syd for Kongeåen blev set som værende uforenelig med mølletvangens fortsatte beståen. Hermed ville kornet som råstof til brænderierne nemlig blive dobbelt beskattet i hertugdømmerne - dels ved den fordyrende formaling under mølletvangen, dels ved selve brænderiafgiften - og dermed stille de derværende brændevinsproducenter dårligere end deres konkurrenter i kongeriget.

Mølletvangens centrale bestemmelse havde været den, at det var 
påbudt indbyggerne i et givet tvangsdistrikt at søge en bestemt mølle (tvangsmøllen) til formaling af deres korn. ${ }^{9}$ Ved mølletvangens ophævelse stod en række forhenværende tvangsmøllere derfor i fare for at miste dele af deres faste kundegrundlag af møllegæster. Forordningen af 21. november 1852 bestemte, at den »kongelige kasse«, med andre ord: statskassen, skulle udbetale en kompensation for dette tab til de tidligere ejere og forpagtere af tvangsmøller. Kompensationens størrelse skulle udfindes ved en formel taksering af hver enkelt mølles skønnede nedgang i indtægter som konsekvens af mølletvangsrettens bortfald. Godtgørelsen skulle som udgangspunkt ydes som fradrag i den årlige grundbyrde, kaldet canon, mølleforpagteren ydede til møllens ejer. I de tilfælde hvor fradraget udgjorde et større beløb end møllens canon, skulle resten af godtgørelsen udbetales mølleren enten kontant eller i kongelige obligationer. Det maksimale erstatningsbeløb var for arveforpagtere en fjerdedel af møllens værdi, for tidsforpagtere en fjerdedel af forpagtningsafgiften. Møllens værdi opgjordes som den pris, den nuværende indehaver i sin tid havde betalt for tvangsmølleprivilegiet $i$ form af en købs- eller forpagtningssum plus det femogtyvedobbelte beløb af møllens årlige canon.

Såfremt en møller ikke ville godtage den tilbudte erstatningssum, levnede forordningen ham $^{10}$ to muligheder: Var han arve- eller tidsforpagter af en kongelig mølle, kunne han overdrage møllen til staten for den oprindelige erhvervelsessum. Den anden mulighed, som også gjaldt forpagtere af de privatejede møller, var at anlægge sag ved domstolene om erstatningsspørgsmålet mod møllens ejer. Ved de kongelige møller anlagdes sagen i så fald direkte mod regeringen. Ved de private møller havde både mølleejer og mølleforpagter mulighed for at gå rettens vej, idet førstnævnte kunne lægge sag an mod regeringen, mens sidstnævnte kunne sagsøge møllens ejer, hvis han som forpagter fandt, at den godtgørelse, mølleejeren blev stillet i udsigt af regeringen, på den ene eller anden måde brød med betingelserne i hans forpagtningskontrakt. ${ }^{11}$ Et mindre antal tvangsmøllere havde som en del af deres forpagtningsaftale givet afkald på erstatning ved en eventuel ophævelse af mølletvangen og var derfor ikke berettiget til nogen kompensation. Det gjaldt blandt andre forpagterne af Hørup Mølle og Asserballe Mølle på Als samt Lille Rundemølle i Aabenraa Amt. ${ }^{12}$

Der fandtes ved midten af 1800-tallet knap 170 møller med mølletvangsrettigheder i hertugdømmet Slesvig. ${ }^{13}$ Af disse var ca. 125 kon- 


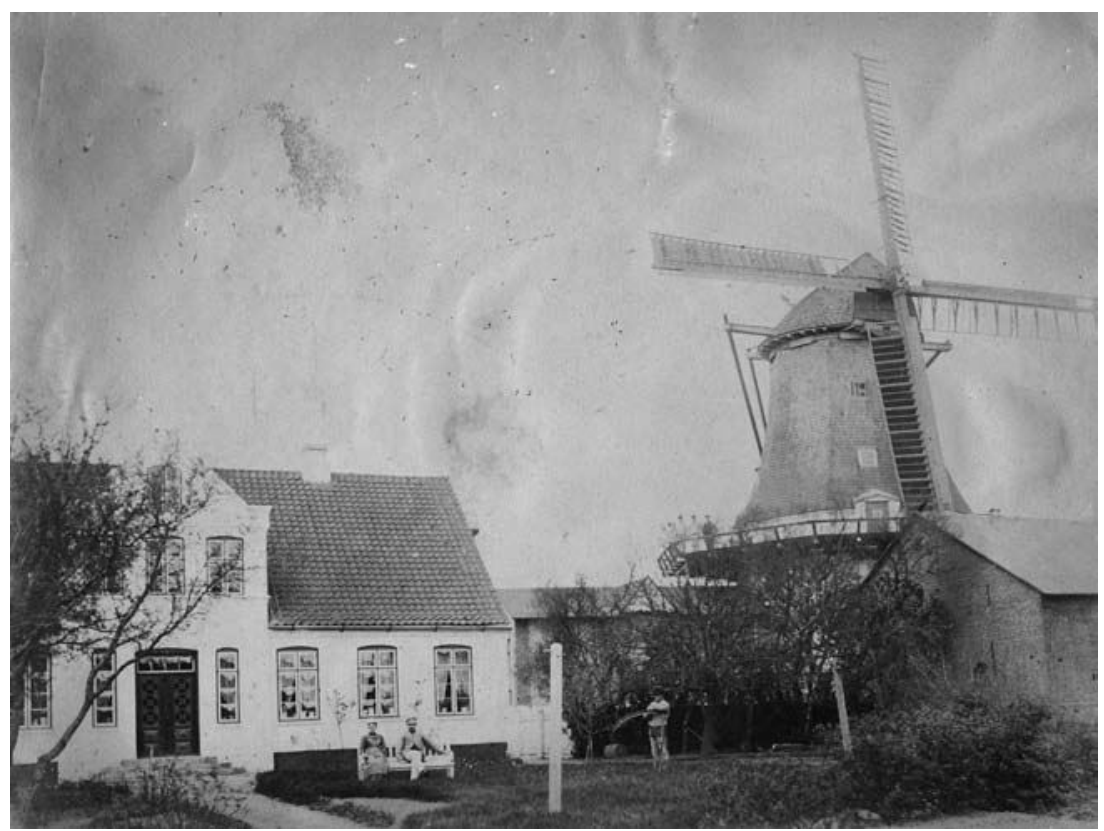

Højer Mølle var én af flere møller, der opførtes i årene umiddelbart efter mølletvangens ophævelse. Billedet er taget omkring 1900. Foto: Højeregnens Lokalhistoriske Arkiv.

gelige arve- eller tidsforpagtningsmøller, mens de resterende møller var i privateje. ${ }^{14}$ Tvangsmøllernes antal lå ikke fuldkommen fast. Enkelte møllers juridiske status var usikker, således at det først i forbindelse med taksationen kom frem, om møllen tilhørte den ene eller den anden kategori, eller endda hvorvidt den overhovedet var at betragte som en tvangsmølle. ${ }^{15}$ Desuden skete der ændringer i ejerskabsformen til flere møller i forbindelse med mølletvangens ophævelse, idet møllerne enten frasolgtes af regeringen eller overgik fra tids- til arveforpagtning. Alle møllerne skulle som udgangspunkt takseres i forbindelse med mølletvangens ophævelse. Ved seks møller fandt der dog ingen taksationer sted, hovedsagelig fordi tidsforpagtningskontrakterne, hvorpå disse var taget i besiddelse, udløb umiddelbart før 1. januar 1853. ${ }^{16}$

Fællesnævneren for de møller, der skulle takseres, var altså tvangsretten og til dels besiddelsesformen. Men hermed ophørte omtrent lighederne. Møllernes tvangsdistrikter varierede således ganske meget i størrelse og udformning. I Nordborg Amt talte f.eks. det 
mindste tvangsdistrikt omkring 400 (Brandsbøl Mølle), det største op imod 3.500 indbyggere (Marstal Mølle på Ærø). ${ }^{17}$ Dertil kom, at mens nogle tvangsdistrikter tilnærmelsesvis udgjorde et, geografisk set, sammenhængende hele, var andre distrikter mere udspredte og fordelt på mange jurisdiktioner. Ved den førnævnte Asserballe Mølle fulgte tvangsdistriktet sognegrænsen, således at hele Asserballe Sogn med ca. 800 indbyggere hørte under møllen. Dertil kom godt 500 indbyggere i tre omkringliggende landsbyer, som var møllepligtige til Asserballe Mølle, når deres ordinære tvangsmølle lå stille. ${ }^{18}$ Tvangsdistriktet til den i Aabenraa Amt beliggende Hellevad Mølle talte derimod godt 350 gårde og huse fordelt på over 20 forskellige landsbyer. ${ }^{19}$ Endelig varierede møllernes kondition meget. Mens nogle møller, såsom Tørning Mølle i Haderslev Amt, havde været genstand for omfattende investeringer i produktionsapparatet, fremstod andre møller, som tvangsmøllen i Marstal, mere forsømte og utidssvarende. ${ }^{20}$ Det var altså møller af vidt forskellig beskaffenhed, taksatorerne i hertugdømmet skulle besigtige.

\section{Taksationerne af møllernes tab}

Efter udstedelsen af forordningen tøvede regeringen ikke med at igangsætte dens implementering. I løbet af december 1852 sendte ministeriet besked til amtmændene om at iværksætte forberedelser til mølletaksationerne. De første taksationer afholdtes i begyndelsen af 1853. ${ }^{21}$ Tvangsmøllerne på Ærø og i det tidligere augustenborgske godsdistrikt på Als blev alle takseret i løbet af januar. De kongelige arveforpagtningsmøller i Aabenraa Amt takseredes i første halvdel af februar. I Nordborg Amt foretoges taksationerne på hovedparten af de derværende kongelige arveforpagtningsmøller i løbet af forårsmånederne. I Tønder, Løgumkloster og Haderslev Amter var så godt som alle forhenværende tvangsmøller blevet takseret inden udgangen af august 1853. Denne del af reformen blev altså ført hurtigt ud i livet.

Til at foretage vurderingerne af de enkelte møllers tab indsattes grupper på omkring fire taksationsmænd. Taksatorhvervet var en slags borgerligt ombud og varetoges således af folk af forskellige erhverv. Disse skulle være »de mest forstandige husfædre, der er almindelig bekendte for retskaffenhed og god opførsel «. ${ }^{22}$ Desuden var det et lovfæstet krav, at der blandt taksationsmændene skulle være repræsenteret håndværkssagkyndige. For deres deltagelse i vurderin- 
gerne modtog hver taksator diætpenge, et vederlag for selve taksationen samt en mindre sum i befordringsgodtgørelse. Taksationerne lededes almindeligvis af den lokale herreds- eller sognefoged; kun i enkelte tilfælde blev taksationen styret af amtmanden.

Fremgangsmåden var i princippet den samme ved alle taksationer af tidligere tvangsmøller i hertugdømmet. Først opstillede taksatorerne et skøn over den ventede til- og afgang af møllegæster efter mølletvangens ophævelse. Var der tale om en samlet tilgang til møllen, beregnedes ingen skade for løsningen af tvangsbåndet, hvad angår malepligten. Det gjaldt f.eks. Havnbjerg Mølle i Nordborg Amt. Taksatorerne vurderede, at skønt møllen ville tabe ca. 50 møllegæster som følge af tvangsrettens ophævelse, ville den til gengæld modtage en tilgang på op imod 400 nye malesøgende fra omkringliggende tidligere mølledistrikter. ${ }^{23}$ Hovedparten af mølletaksationerne konkluderede dog modsat, at mølletvangens ophør samlet set ville forårsage en nedgang i kundemængden. Hvad enten det ene eller det andet resultat fremkom, var sådanne adfærdskalkuler stærkt skønsmæssige og havde i det mindste to store usikkerhedsmomenter. For det første toges det for givet, at de tidligere tvangsgæster efter mølletvangens ophævelse altid ville søge nærmeste mølle. I realiteten var den geografiske afstand imidlertid blot ét af flere parametre af betydning for, hvilken mølle et givet områdes beboere valgte. Andre overvejelser, såsom vejenes beskaffenhed, personlige forbindelser til mølleren samt frem for alt den påregnede maletid, simpelthen at kunne nå ud og hjem samme dag, havde også indflydelse på beslutningen. ${ }^{24}$ For det andet kendte ingen, heller ikke taksatorerne, fremtidens møllelandskab. Udstedelsen af blot en enkelt ny møllekoncession i et område kunne forrykke balancen med hensyn til møllegæsternes anslåede antal fuldstændig. Muligheden, eller set fra tvangsmøllernes synspunkt, risikoen for møllegrundlæggelser efter mølletvangens ophævelse indgik ikke i taksatorernes beregningsgrundlag, om end der i flere taksationsrapporter blev taget forbehold i denne retning. Efter at have bestemt nettoresultatet af de forventede forskydninger i antallet af møllegæster omregnedes dette, såfremt det var negativt, til et pengebeløb. Hertil lagde taksatorerne den skønnede værdi af de til mølletvangen knyttede arbejdspræstationers bortfald. Også dette måtte i sagens natur få et lidt vilkårligt udfald, da møllehoveriets karakter varierede fra mølle til mølle og derfor ikke ubetinget lod sig omsætte til en objektiv, pekuniær (pengemæssig) størrelse. Totalsummen udgjorde 


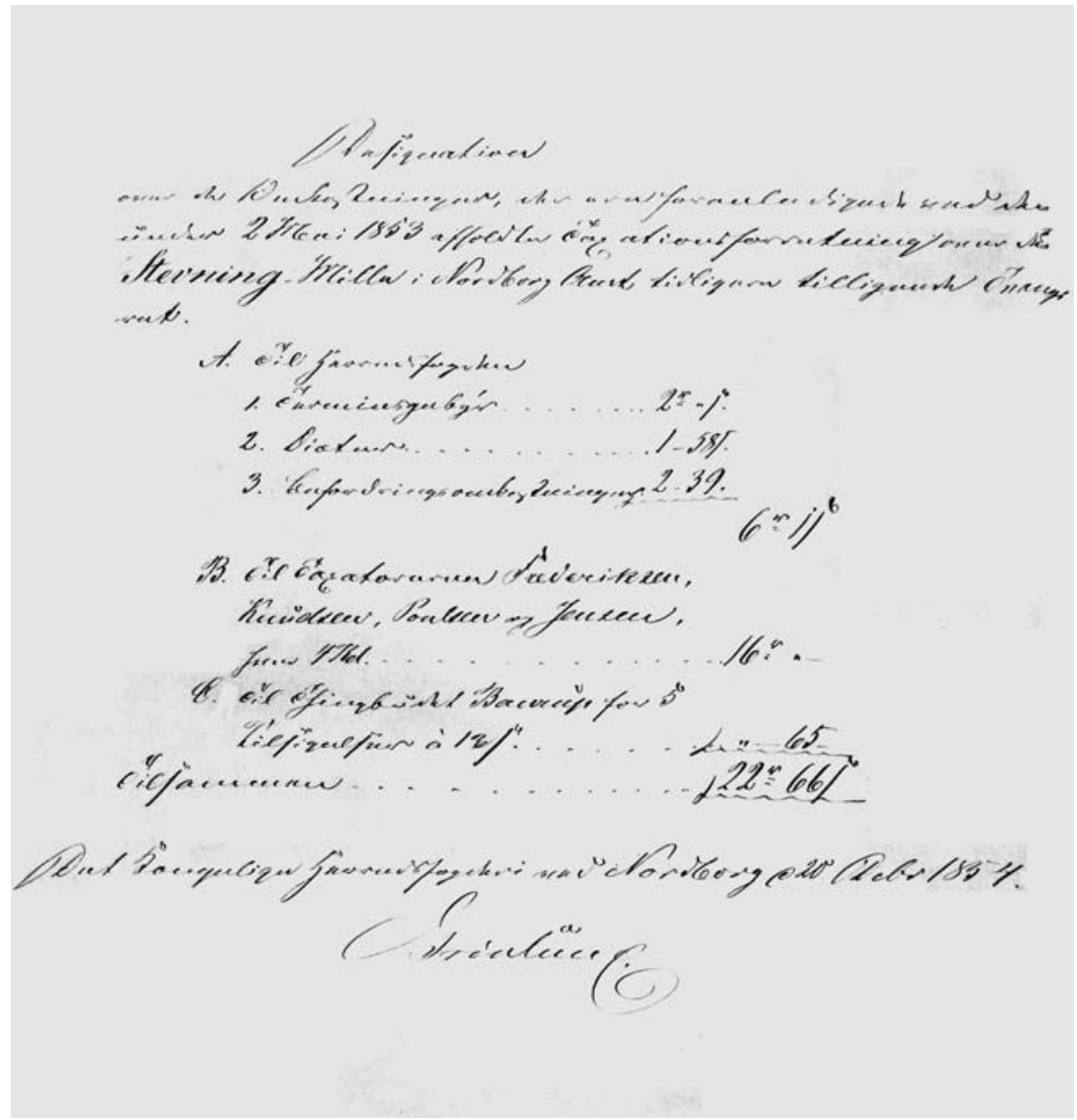

Designation, dvs. fortegnelse, over de udgifter som blev afholdt $i$ forbindelse med taksationen af Stevning Mølle i Nordborg Amt d. 2. maj 1853. Af skrivelsen fremgår det bl.a., at den lokale herredsfoged modtog et terminsgebyr og dixtpenge, samt fik dækket sine befordringsomkostninger. Foto: Rigsarkivet, Ministeriet for Hertugdømmet Slesvig.

det takserede erstatningsbeløb. Selv om dette af de ovennævnte grunde næppe var helt retvisende, repræsenterede det trods alt et kvalificeret skøn baseret på den enkelte mølles særegne forhold.

En typisk mølletaksation var taksationen af Store Rundemølle i Aabenraa Amt foretaget 12. februar 1853. Et taksatorkorps, bestående af sognefogeden, en bager fra Aabenraa købstad, en sandemand ${ }^{25}$ fra Nybøl og en møllesagkyndig fra Genner slibemølle, mødte frem på Store Rundemølle for at vurdere møllens tab ved tvangsrettens ophæ- 
velse. ${ }^{26}$ Møllens tidligere tvangsdistrikt opgjordes til 122 gårde og 244 huse, hvoraf de 19 gårde og de 18 huse skønnedes for fremtiden at ville søge til andre møller. En eventuel tilgang til møllen nævnes ikke i rapporten. Denne nettoafgang af møllegæster takseredes til et tab af 90 rd. cour. ${ }^{27}$ Dertil lagdes omkostningerne ved tabte arbejdsydelser. Hidtil havde mølleren, i kraft af mølletvangsretten, haft krav på forskellige kørselstjenester fra distriktets beboere. Endvidere havde disse været pligtige til årligt at oprense mølledammen og den stedværende dæmning. Det samlede tab ved mølletvangens ophævelse takseredes til en årlig nedsættelse i canon af 210 rd. cour. Da beløbet ikke oversteg en fjerdedel af møllens værdi, blev denne godtgørelsessum tilbudt mølleindehaveren.

Modsat taksationen af Store Rundemølle forløb ikke alle taksationer af tidligere tvangsmøller i hertugdømmet til ministeriets tilfredsstillelse. Den forudgående instruering af taksatorerne havde i flere tilfælde været mangelfuld. ${ }^{28}$ Følgen var, at der ved flere skadesvurderinger blev begået så graverende fejl, at der måtte foretages omtaksationer. Ved taksationerne af Tovskov, Tørning og Ultang Mølle i Haderslev Amt havde der således, skrev ministeriet til amtmanden på baggrund af dennes indberetning, »fundet så store uregelmæssigheder sted, at ministeriet ikke på den kongelige kasses vegne kan acquiseres $^{29}$ ved samme «. ${ }^{30}$ Navnlig det forhold, at taksatorerne ikke havde medtaget omkostningerne ved tvangsarbejdets bortfald i vurderingerne, udgjorde et problem. Også ved den tidsforpagtede Bevtoft Mølle samt Brenduhr arveforpagtningsmølle, begge Haderslev Amt, kom det til omtaksationer. Ved omtaksationerne udskiftedes hele taksatorkorpset på nær den ledende øvrighedsperson.

Mølleren var som udgangspunkt personligt til stede ved taksationshandlingen. Var han forhindret $i$ at give møde, stillede en repræsentant for ham. At dømme efter taksationsrapporterne ${ }^{31}$ spillede møllerne en forholdsvis tilbagetrukket rolle under taksationerne. De stod til rådighed for taksatorerne med oplysninger om forskellige anliggender vedrørende møllen. Naturligvis var der en tilskyndelse til at fremhæve de særlige forhold, der kunne være dem til fordel ved erstatningsbeløbets fastsættelse. Et mindre antal møllere forsøgte imidlertid også mere aktivt at påvirke taksationens udfald. En af disse var møller Asmus Boysen, indehaver af den kongelige arveforpagtningsmølle Tørning Mølle i Haderslev Amt. Da taksatorerne ankom til møllen, mødte Boysen dem med en detaljeret beregning over sit tab 
ved tvangsrettens bortfald, som han forlangte skulle inddrages i taksationen. ${ }^{32}$ En sådan optræden over for de kongelige taksationsmænd hørte sjældenhederne til. Boysen var dog heller ikke, som det senere vil fremgå, en hvilken som helst tvangsmøller.

Efter hver taksations afslutning udfærdigedes en rapport om dens forløb og udfald, som de tilstedeværende underskrev. Herefter indsendtes rapporten til amtshuset, som samlede rapporterne og sendte dem videre til Ministeriet for Hertugdømmet Slesvig i København ledsaget af en følgeskrivelse fra amtmanden. I ministeriet vurderede man de indkomne rapporter under inddragelse af amtmændenes bemærkninger. På dette grundlag udformedes nærmere instruktioner til amtsmyndigheden omkring den sum, hver enkelt tvangsmøller skulle tilbydes som godtgørelse for mølletvangens ophævelse. Hvis mølleren accepterede regeringens tilbud, var han forpligtet til at indsende en »i behørig forbindende form affattet erklæring «, i hvilken han formelt accepterede godtgørelsen og frasagde sig »ethvert [yderligere] krav på den kongelige kasse, der måtte tilkomme ham i anledning af mølletvangens ophævelse «. ${ }^{33}$ I flere tilfælde var ministeriet utilfreds med de indsendte erklæringers formelle ordlyd og pålagde derfor de pågældende møllere at indsende nye erklæringer. Så snart ministeriet havde modtaget en erklæring, og denne var affattet i overensstemmelse med ministeriets ønsker, gik der besked videre til Finansministeriet om at udbetale pengene til vedkommende møller. Ministeriet for Hertugdømmet Slesvig var temmelig nidkært i sine bestræbelser på at få lukket hver enkelt møllesag med en sådan erklæring. Da bønskrifter om at få omstødt regeringens afgørelser i de enkelte erstatningssager begyndte at indkomme til ministeriet (se nedenfor), affærdigedes disse ansøgninger ofte med henvisning til, at der manglede en erklæring fra den pågældende møller. Det skete også i tilfælde, hvor henvendelserne omhandlede forhold, der angik andet end selve taksationsresultatet. Da mølleren på Solvig Vandmølle i Tønder Amt gjorde ministeriet opmærksom på, at han fejlagtigt havde betalt for meget $i$ canon de senere år, fik han det svar, at ministeriet ikke kunne gå videre med sagen, førend han havde afgivet en erklæring om godtgørelsen for mølletvangens ophævelse. ${ }^{34}$

Oftest oversteg det takserede tab en fjerdedel af møllens værdi. ${ }^{35}$ Med andre ord blev flertallet af forhenværende tvangsmøllere tilbudt en godtgørelse, der var lavere end den sum, taksatorerne var kommet frem til. Forskellen mellem det takserede tab og den faktisk ydede 
erstatning kunne være ganske stor: For Hellevad Mølle var skaden ved mølletvangens afskaffelse blevet takseret til et beløb, der var næsten fire gange større end fjerdedelen af møllens værdi. ${ }^{36}$ Det samme gjorde sig gældende med hensyn til Nybøl Mølle i Tønder Amt. ${ }^{37}$ Ved andre mølletaksationer var differencen noget mindre, men stadig markant. For Krusmølle i Aabenraa Amt var forholdet omtrent 2:1. Arveforpagteren af tvangsmøllen i Løgumkloster fik tilbudt 10.300 rd. cour. i erstatning, skønt bortfaldet af hans tvangsret var blevet takseret til godt $13.500 \mathrm{rd}$. cour. - et beløb han i øvrigt var stærkt utilfreds med. Det generelt store spænd mellem godtgørelsessummen, når den var baseret på møllens værdi, og når den var grundet på taksation, foranledigede en bølge af henvendelser til ministeriet fra de tidligere tvangsmøllere.

\section{Tvangsmøllernes reaktioner på mølletvangens ophævelse}

Som nævnt fik knap 170 møller ophævet deres tvangsret med forordningen af 21. november 1852. Alle disse møller var stort set blevet takseret ved udgangen af august 1853. Alligevel blev kun knap 50 sager afsluttet med udbetaling af godtgørelse til tidligere tvangsmølleindehavere inden for det første år efter mølletvangens afskaffelse. ${ }^{38}$ De resterende ca. 120 tvangsmøllere havde så godt som alle tøvet med at afgive en erklæring. Hvad holdt dem tilbage? Var mølleren ikke tilfreds med godtgørelsen, kunne han, som nævnt ovenfor, vælge enten at tilbagegive møllen eller at indlede en retsproces mod mølleejeren, som oftest staten. Forordningens ord var i denne henseende fuldkommen klare. Mange møllere foretrak dog at se tiden lidt an, inden de traf beslutning i sagen. Typisk erklærede de umiddelbart efter taksationen over for amtmanden, at de fandt regeringens tilbud utilfredsstillende, men undlod i øvrigt at oplyse, hvilken af de to muligheder i forordningen, de så ville gøre brug af. Dermed købte de sig tid. Mølleren på Ultang Mølle var én af mange, som forfulgte denne taktik. Han skrev herom senere til ministeriet: "Jeg kan vel ikke fortænkes i, at jeg dengang smertelig bevæget af den tilbudte godtgørelses ubetydelige beløb i forhold til den netop ved min mølle så betydelige skade, mølletvangens ophør havde forårsaget, ikke straks erklærede mig tilfreds med tilbuddet, men ved foreløbig at forbeholde mig de ved forordningen hjemlede andre alternativer søgte at vin- 
de tid, for senere muligvis at kunne bevæge det kongelige ministerium til at bevilge mig en mere til det lidte tab svarende godtgørelse.«39 Lige så vedholdende regeringen var med at få afæsket de tidligere tvangsmøllere en formel erklæring om, at de afsagde sig tvangsretten, lige så tilbageholdende var flertallet af møllere med at afgive denne erklæring. Mølleren på Melsgaard Mølle på Als, som var blevet tilbudt en erstatningssum, der var $1000 \mathrm{rd}$. cour. lavere end det takserede tab, udbad sig i efteråret 1853 betænkningstid, hvorefter han indsendte en ansøgning til ministeriet om at modtage taksationssummen frem for den tilbudte godtgørelse. ${ }^{40}$ Også mølleren på Nybøl Mølle ansøgte ministeriet om at få forhøjet den tilbudte erstatningssum i overensstemmelse med den værdi, der var blevet udfundet ved taksationen. Som mølleren skrev: »Møllens ugunstige beliggenhed har nu haft så stor en afgang til følge, at der næsten ikke en eneste er tilbage af de forrige møllegæster, og på den anden side er tilgangen så ubetydelig, at den [tilbudte godtgørelse] ikke i fjerneste måde kan betragtes som erstatning for, hvad møllen har mistet. «11 Endelig ansøgte også mølleren på Marstal tvangsmølle på Ærø ministeriet om en større godtgørelse. Mølletvangens ophævelse havde bragt et så stort fald i hans beskæftigelse, at han »fra udsigt til et anstændigt erhverv, fra udsigt til anstændigt at kunne forsørge kone og børn «, nu så sig »bragt bettelstaven nær «. ${ }^{42}$ En række møllere ansøgte tillige om at modtage hele eller en del af erstatningsbeløbet kontant frem for ved afdrag i canon. ${ }^{43}$ Atter andre forsøgte at opnå tilsagn fra ministeriet om, at der ikke ville blive koncessioneret nye møller i deres område i årene fremover. Samtlige ansøgninger afsloges af ministeriet. $^{44}$

I takt med ministeriets afslag på møllernes ansøgninger måtte stadig flere tvangsmøllere nødtvungent acceptere regeringens erstatningstilbud. Således afsluttedes yderligere godt 70 sager med udbetaling af godtgørelse for mølletvangens ophævelse i løbet af $1854 .{ }^{45} \mathrm{Kun}$ et mindretal af møllerne benyttede sig af forordningens to alternative handlemuligheder. Den første mulighed, fratrædelse af mølleforpagtningen, blev taget $\mathrm{i}$ anvendelse af $\mathrm{i}$ alt otte forhenværende indehavere af tvangsmølleprivilegier, heraf de seks fra Sydslesvig. ${ }^{46}$ At så relativt få møllere gjorde brug af denne lovhjemlede ret, havde to hovedårsager. For det første betød den generelle udvikling i ejendomspriserne de foregående årtier, at den på erhvervelsestidspunktet betalte sum ofte var lav i forhold til mølleprivilegiets nutidige værdi. 
Derved stod en del møllere til at inkassere et stort, i nogle tilfælde nok nærmest ubærligt, tab, hvis de valgte at lade møllen gå tilbage. Indehaveren af tvangsmøllen i Alkersum på Før havde f.eks. erhvervet sin tvangsmølle i 1840 i forbindelse med et mageskifte ${ }^{47}$ for en værdi af 1653 rd. cour. I maj 1853 - altså få måneder efter mølletvangens ophævelse - solgte han møllen for 5866 rd. cour. ${ }^{48}$ Havde han i stedet givet møllen tilbage efter forordningens bestemmelse, ville han kun have modtaget under en tredjedel af denne sum, nemlig de 1653 rd. cour. En anden tvangsmøller beklagede sig til ministeriet over, at »den sum, for hvilken møllen til en tid blev overdraget mig, hvor al fast ejendom så at sige var værdiløs eller dog stod på et yderst lavt trin [...], er blevet lagt til grund for ejendomsvurderingen for at udfinde fjerdedelen «. ${ }^{49}$ I flere tilfælde var mølleejendommen overgået til den nuværende indehaver, uden at der var blevet betalt en egentlig købesum. ${ }^{50}$ Typisk var mølleprivilegiet gået i arv fra fader til søn, eventuelt mod at sidstnævnte skulle svare aftægtsydelser til den afgåede møller. I sådanne tilfælde fastholdt regeringen i reglen den seneste erhvervelsessum som beregningsgrundlag for kompensationens størrelse. Det ramte f.eks. indehaveren af Nybøl Mølle, som fik sin godtgørelse udregnet på baggrund af faderens køb af møllen i 1822.

For det andet nødvendiggjorde en opgivelse af møllen oftest et brancheskifte. Denne omstændighed virkede uden tvivl afskrækkende på mange. Det gjaldt f.eks. mølleren på Vibæk Mølle i Sønderborg Amt. Hans tab ved mølletvangens ophævelse var blevet takseret til godt 3000 rd. cour., men da en fjerdedel af værdien af tvangsmøllen plus udbygning kun udgjorde $2500 \mathrm{rd}$. cour., var han blevet tilbudt denne sidstnævnte sum i erstatning. Mølleren kunne nu i foråret 1854 meddele regeringen, at da »jeg som en svag og sygelig mand i en fremrykket alder, ikke kan slå ind på en ny næringsvej og altså ikke kan afstå min mølle til regeringen for hvad, jeg har erhvervet den [for], og hverken har evne eller lyst til at søge rettens vej, så har jeg efter moden overvejelse fundet det fornuftigt at gå ind på regeringens tilbud « ${ }^{51}$ For denne møller, som for mange andre møllere, oplevedes valget mellem forordningens muligheder nok mindre frit, end lovens indhold lagde op til.

Hvad angår den anden valgmulighed, retssag mod mølleejeren, erklærede en betydelig andel af de tidligere tvangsmøllere efter taksationen at ville gå denne vej. ${ }^{52}$ Det var imidlertid kun et fătal af møllerne, som fulgte op på denne udmelding og reelt indledte en retsproces. 


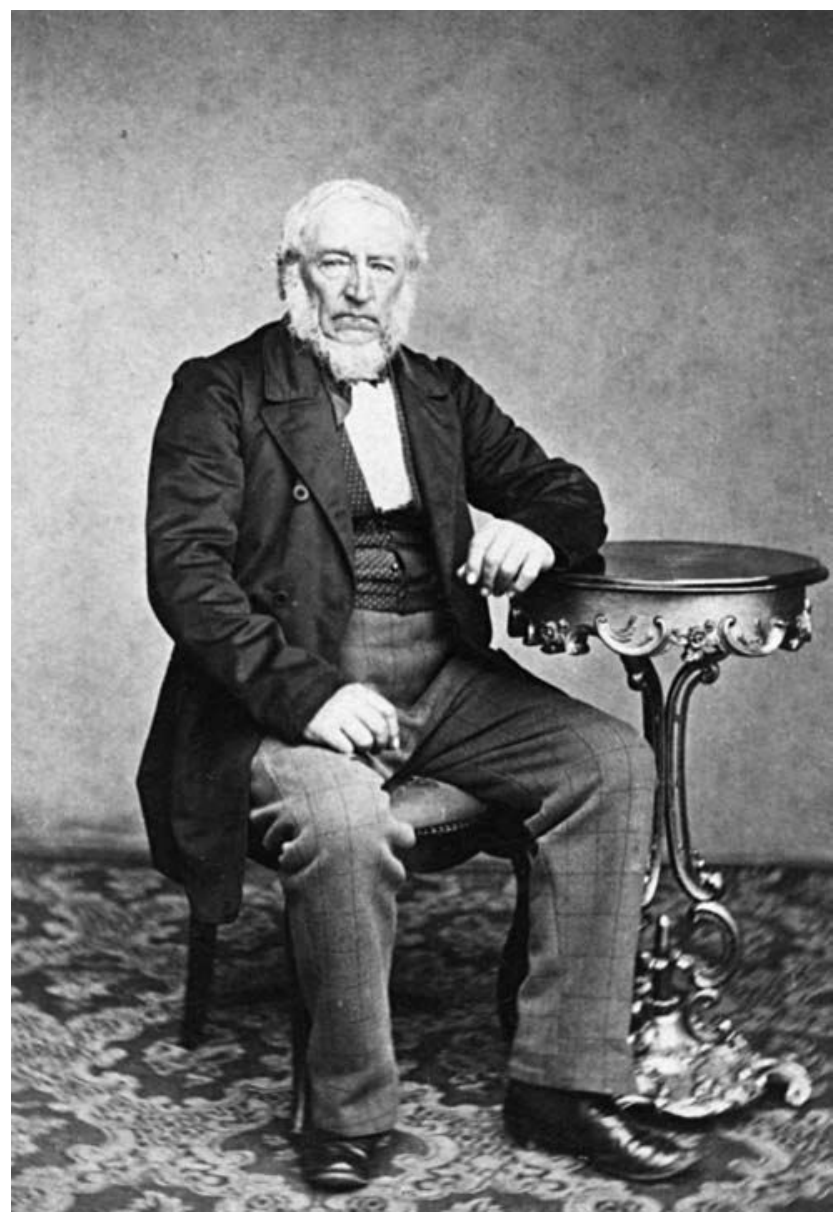

Asmus Boysen (1800-1883): Boysenfamilien var ét af flere mølledynastier $i$ hertugdømmet Slesvig. Foto: Lokalhistorisk Arkiv for Vojens-området.

Mølleren fra Vibæk meddelte i den ovenfor citerede skrivelse også ministeriet, at det »aldrig er faldet mig ind, virkelig at ville føre proces mod den kongelige kasse«. I Haderslev søgte en advokat, som skulle føre erstatningssager mod regeringen for flere tvangsmøllere, gentagne gange om udsættelse af retssagerne på sine klienters vegne. ${ }^{53} \mathrm{Og}$ på Brenduhr Mølle lykkedes det mølleren, som havde erklæret at ville tage rettens vej frem for at modtage regeringens erstatningstilbud, at trække sagen i tre år. Først da den kongelige oversagfører i Flensborg i februar 1857 satte tommelskruerne på og forlangte 
en endelig erklæring, bøjede mølleren sig og accepterede den tilbudte godtgørelse for mølletvangens ophævelse. ${ }^{54}$

Der var dog møllere, som gjorde alvor af hensigtserklæringerne. Navnlig én af disse sager er iøjnefaldende: Sagen som arveforpagtningsmøller Asmus Boysen på Tørning Mølle førte mod regeringen. ${ }^{55}$ Boysen (1800-1883) var fra begyndelsen forkæmper for møllernes rettigheder i forbindelse med mølletvangens ophævelse. Således hævdede han at repræsentere 48 tidligere tvangsmøllere i hertugdømmet Slesvig, da han i januar 1853 sendte et næsten 30 siders langt skrift omhandlende mølletvangens ophævelse til regeringen. ${ }^{56}$ I andragendet søgtes det med henvisning til gældende lovgivning bl.a. godtgjort, at mølletvangens ophævelse var en form for ekspropriation, for hvilken de tidligere tvangsmøllere havde krav på fuld erstatning - ikke kun en godtgørelse. Skønt ministeriet afviste ansøgningen begrundet med en procedurefejl, viste sagen, at møllerne ikke passivt ville se til, at deres tvangsrettigheder blev ophævet. Møller Boysen var i øvrigt allerede en kendt skikkelse i lokalsamfundet. Hans omgangskreds talte flere fremtrædende sønderjyder såsom Laurids Skau. Desuden havde han kapitalstyrke nok til ved mindst to lejligheder at kautionere for fagfæller ved deres køb af møller. ${ }^{57}$

Som nævnt havde der fundet betydelige uregelmæssigheder sted ved den ordinære taksation af Tørning Mølle, hvad der udløste en omtaksation. Denne taksation ansatte det lidte tab ved tvangsrettens ophævelse til knap 38.000 rd. cour. Ifølge regeringen var møllen i faderens testamente blevet overdraget til Asmus Boysen for $14.400 \mathrm{rd}$. cour. Erstatningssummen skulle, når man til dette beløb lagde den femogtyvedobbelte canon og tog en fjerdedel, udgøre $6600 \mathrm{rd}$. cour. Boysen på sin side hævdede modsat regeringens opfattelse hårdnakket, at beløbet i testamentet ikke var en overdragelsessum. Det var derimod nogle penge, han efter faderens vilje skulle give til sin mor, fordi hun havde investeret en del af sin familieformue i møllen. Boysen påstod endvidere, at faderen kort før sin død var blevet tilbudt 80.000 rd. cour. for møllen. Denne sum og ikke de 14.400 rd. cour., mente han, skulle lægges til grund for godtgørelsens udmåling. Regeringen stod imidlertid fast på sit. Den 1. juli 1854 erklærede Boysen, at han afslog regeringens tilbud, og at han ville gøre sin ret gældende ved domstolene. Derved blev det. Ved en foreløbig dom i februar 1856 pålagde underretten Boysen at fremlægge dokumentation for sin påstand om møllens værdi. Boysen havde imidlertid ikke noget 


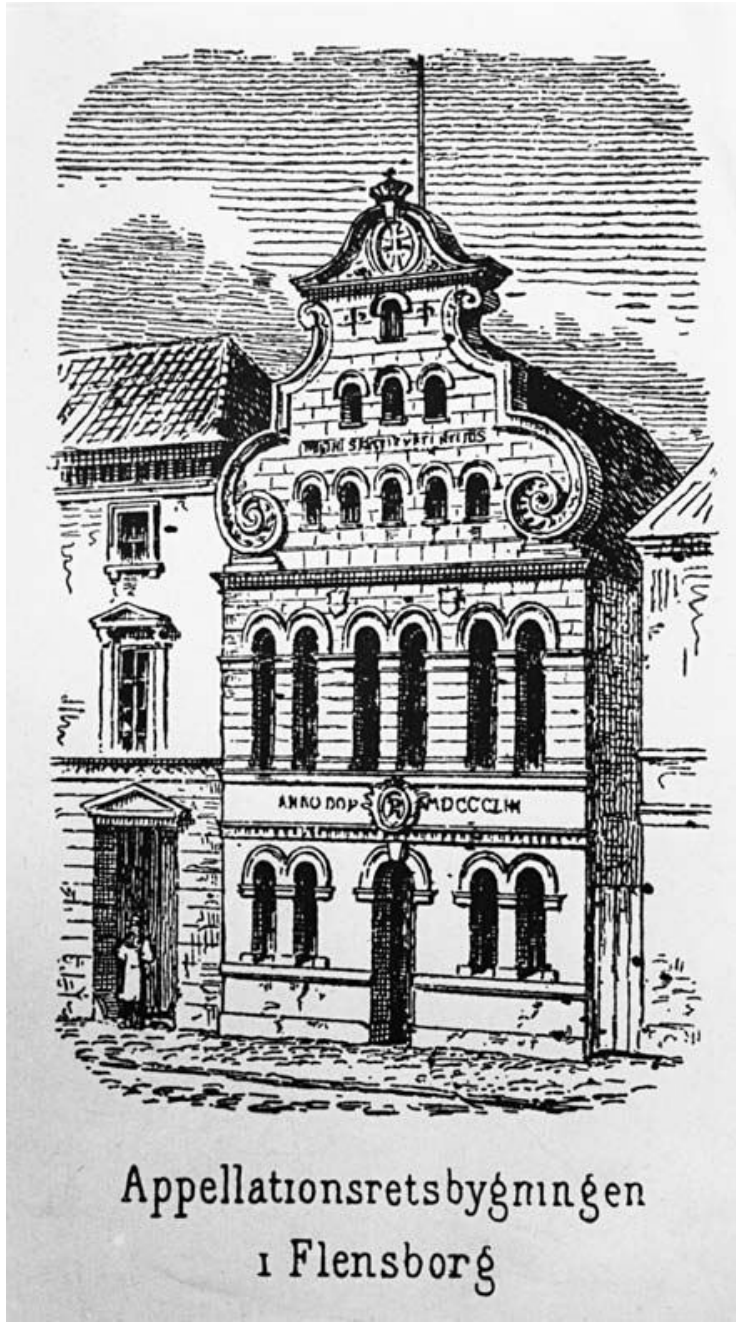

Den Kongelige Appellationsret i Flensborg behandlede mange af retssagerne om mølletvangens ophævelse. Appellationsretten, som blev grundlagt $i$ 1852, var øverste retsinstans $i$ hertugdømmet Slesvig i perioden mellem de slesvigske krige. Foto: Arkivet ved Dansk Centralbibliotek for Sydslesvig.

skriftligt bevis for købstilbuddet til faderen. Advokaten, der førte Boysens sag, gjorde i et brev til Ministeriet for Hertugdømmet Slesvig opmærksom på denne omstændighed, og opfordrede til et forlig mellem parterne: »Jeg har alt tidligere foreslået min klient at indgå med 
et underdanigst andragende til det høje ministerium for at forsøge, om man ikke ad overenskomstens vej kunne få noget af det, der nu kæmpes om, og ganske vist for min klient med ulige våben, da bevisbyrden vil falde på ham for noget, man ikke tidligere havde tænkt sig at sikre sig beviset for. «58 Ministeriet svarede, at det gerne ville indgå forlig med Boysen, men at det ikke var villig til at yde ham mere end det oprindelige tilbud. Maj 1857 afsagde appellationsretten i Flensborg, hertugdømmets øverste retsinstans, dom i sagen: Boysens klage afvistes, og han blev pålagt at betale sagens omkostninger. Efter domfældelsen meddelte ministeriet gennem oversagføreren i Flensborg Boysen, at han på grund af sagens udfald ikke længere var berettiget til nogen erstatning for bortfaldet af mølletvangen. Han skulle dog stadig afgive en erklæring som de øvrige møllere, hvori han frasagde sig ethvert krav på fremtidig erstatning for mølletvangens ophævelse. En lignende fremfærd fra regeringens side over for andre møllere, som tabte deres retssager om erstatningsspørgsmålet, synes ikke at have forekommet. Man havde sandsynligvis set sig sur på mølleren fra Tørning Mølle.

Boysen var dog ikke slået. Oktober 1857 indsendte han et langt og velformuleret andragende til ministeriet om sagen. Efter eget udsagn var Boysen den eneste møller i hertugdømmet Slesvig, der ikke var blevet behandlet efter lovens bogstav i forordningen om mølletvangens ophævelse. Det kunne »ikke nægtes, at det kongelige ministerium har villet gøre det, har troet at have gjort det, men det har ikke gjort det«, skrev Boysen. Dernæst opridsede han sagsforløbet og gentog sin påstand om, at de 14.400 rd. cour. ikke var en købssum, men en erstatning til moderen for hendes investeringer i møllen. Møllens værdi måtte snarere ansættes til $100.000 \mathrm{rd}$. cour. Hvis regeringen ikke var villig til at yde ham godtgørelse for mølletvangens ophævelse på basis af dette beløb, anmodede han om, alternativt at måtte blive tildelt en koncession på møllenæring i enten Øsby eller Jels Sogn. Sideløbende hermed indledte han en ny retssag mod regeringen.

November 1857 udbad regeringen sig amtmandens betænkning omkring Boysens koncessionsansøgning. Svaret forelå i begyndelsen af 1858. Amtmanden kunne her berette, at der var stor mølletrang ${ }^{59} \mathrm{i}$ begge sogne. Samtidig havde de lokale sognefogeder i Øsby og Jels, fra hvilke amtmanden havde indhentet oplysninger, benyttet lejligheden til at levere et kraftigt forsvar for Asmus Boysen i sagen mod regeringen. Alligevel meddelte ministeriet marts 1858 Boysen, at hans 
ansøgning om en møllekoncession afsloges. Til gengæld ville regeringen, »for at bevirke sagens hurtige afgørelse«, genfremsætte sit tilbud til Boysen om en godtgørelse på 6600 rd. som kompensation for mølletvangens ophævelse. Denne, set fra regeringens synspunkt, udstrakte hånd afviste Boysen imidlertid. For ham var det ikke blot et økonomisk spørgsmål, men i lige så høj grad en principsag.

Den verserende retssag mod regeringen var blevet udsat, mens behandlingen af Boysens koncessionsansøgning pågik. November 1858 afsagde underretten, akkurat som første gang, en kendelse, hvori Boysen pålagdes at fremlægge dokumentation for sin påstand om møllens værdi. Da Boysen som bekendt ikke kunne efterkomme dette krav, gik appellationsrettens endelige dom i sagen mølleren imod. »Det glæder mig at kunne meddele«, skrev oversagføreren til regeringen juni 1859, »at sagen således nu definitivt er påkendt og ikke vil kunne leve op igen i en anden skikkelse«. Det gjorde sagen nu på en måde alligevel. Efter at have udtømt sine muligheder ved domstolene, havde Boysen tænkt sig at indlevere en petition til den slesvigske stænderforsamling om sagen. Da tilsmilede heldet pludselig mølleren fra Tørning Mølle. I København var der i begyndelsen af december 1859 foregået et regeringsskifte, hvorved Ministeriet for Hertugdømmet Slesvig blev overtaget af grev Blixen-Finecke. Allerede knap tre måneder senere var denne regering faldet og Ministeriet for Hertugdømmet Slesvig på ny besat af H.F. Wolfhagen, der havde været minister for Slesvig uafbrudt siden oktober 1856, altså også mens retssagerne mod Boysen foregik. Under Blixen-Fineckes kortvarige embedsperiode havde Boysen nu truffet denne i Flensborg, og ministeren havde ved denne lejlighed lovet at tage Boysens sag op til genovervejelse. ${ }^{60} \mathrm{Da}$ Wolfhagen atter overtog ministeriet, var sådanne tiltag allerede sat i værk. Dermed blev hele sagen genåbnet, og Boysen fik sat igennem, at der skulle foretages en tredje taksation af hans mølleejendom. Denne taksation kom frem til et godtgørelsesbeløb, der var næsten tre gange så højt som regeringens oprindelige erstatningstilbud. For Asmus Boysen betød det, at hans vedholdenhed havde båret frugt. Efteråret 1862 indgav han som én af de sidste forhenværende tvangsmøllere i hertugdømmet Slesvig en erklæring om, at han godtog regeringens tilbud om godtgørelse for mølletvangens ophævelse. 


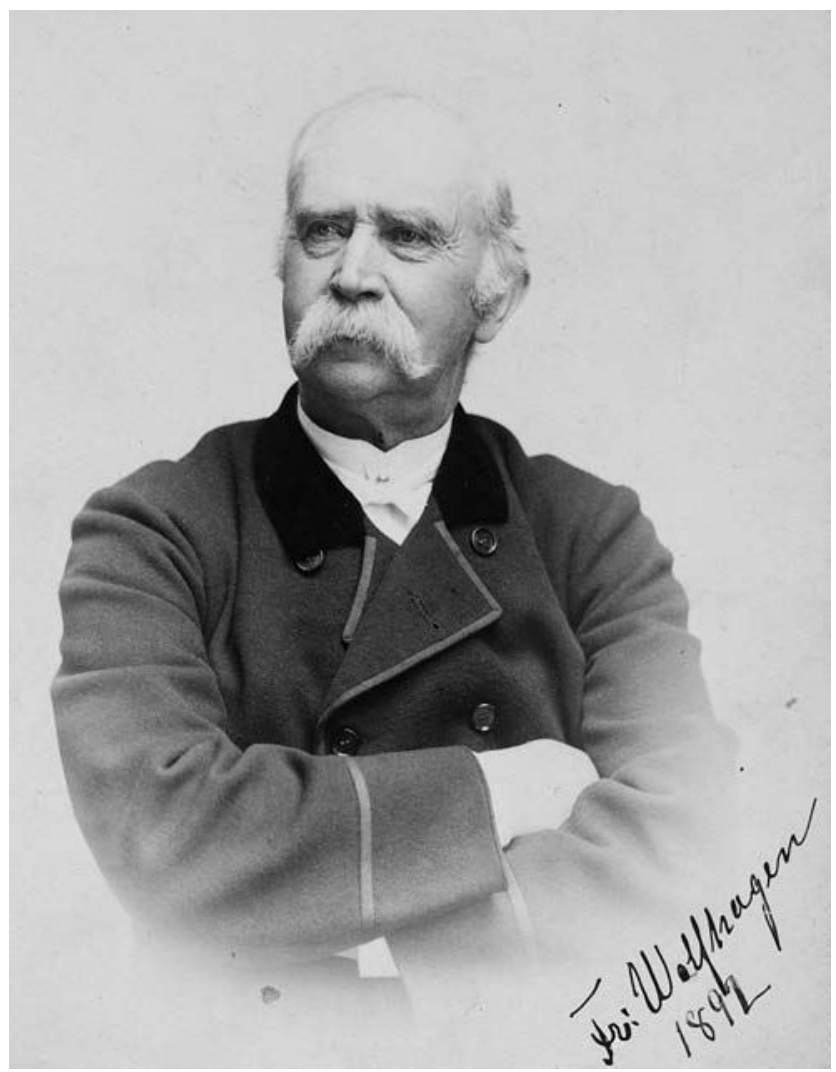

Friedrich Hermann Wolfhagen (1818-1894), minister i Ministeriet for Hertugdømmet Slesvig 1856-1863 (med en enkelt afbrydelse). Forinden udnæonelsen til minister havde en del af hans embedsarbejde foregået $i$ Haderslev og Flensborg Amter. Foto: Det Kongelige Bibliotek.

\section{Mølletvangens ophævelse i stænderforsamling og rigsråd}

Forordningen om afskaffelsen af mølletvangen i hertugdømmet Slesvig udgik fra den enevældige kongemagt. Regeringen behøvede derfor ikke at forelægge den slesvigske stænderforsamling loven til gennemsyn, før den udstedtes. Da forsamlingen i oktober 1853 trådte sammen for første gang inden for rammerne af den rekonstruerede helstat, var det til gengæld naturligt, at stænderne fik mulighed for at udtale sig om mølletvangens afskaffelse. På det tidspunkt var for- 
ordningens implementering som bekendt vidt fremskreden. Det udvalg, som stænderforsamlingen nedsatte til at behandle loven om mølletvangens ophævelse, erkendte da også, at forsamlingens betænkning om spørgsmålet syntes at være af »underordnet praktisk betydning «. ${ }^{61}$ På den anden side havde man nu erfaret, hvordan reformen virkede i praksis. Det styrkede på flere punkter udvalgets indsigelser imod forordningen.

Udvalget var stærkt besat med møllere og personer med mølleinteresser. ${ }^{62}$ Denne personkreds havde ikke overraskende en række ændringsforslag, heraf nogle ganske vidtgående, til forordningen. Da udvalgets kommentarer må betragtes som et fremstød for de forhenværende tvangsmølleres sag, skal hovedpunkterne i komiteens betænkning her skitseres. ${ }^{63}$ For det første ønskede man, at ordet "godtgørelse « i forordningen skulle stryges til fordel for »fuldstændig erstatning «. Denne fordring støttede sig på en opfattelse af mølletvangens afskaffelse som en decideret ekspropriation, altså samme argument som Asmus Boysen havde fremsat i møllernes henvendelse til regeringen. For det andet foreslog udvalget, at én og samme embedsmand skulle lede samtlige taksationsforretninger på hertugdømmets tidligere tvangsmøller for derigennem at sikre et mere ensartet resultat. Desuden skulle loven indeholde nøje fastlagte kriterier for taksationerne, således »at samtlige erstatningens arter i almindelighed optages i forordningen «. Denne anskuelse udmøntede udvalget i syv underpunkter. Ifølge ét af disse punkter skulle taksatorerne ved vurderingerne af tabet ved mølletvangens ophævelse tage hensyn til »kvantiteten af det hidtil af den tvangsberettigede til tvangsdistriktets behov formalede tvangspligtige korn af enhver art, og er dermed at tage hensyn til distriktets størrelse og befolkning, som og til befolkningens sædvaner, levemåde og øvrige forhold «. Denne formulering må siges at være så tilpas bred, at de øvrige seks punkter ikke behøver at omtales nærmere her. For det tredje fandt udvalget det urimeligt, at en fjerdedel af møllens værdi udgjorde godtgørelsens maksimum. Man fremhævede her de tidligere nævnte forhold omkring møllens overgang fra fader til søn samt de stigende ejendomspriser. For det fjerde forkastede udvalget forordningens bestemmelse om, at møllerne kunne anlægge sag ved domstolene, hvis de var utilfredse med den tilbudte erstatningssum. Langt hellere måtte mølleren have mulighed for at forlange en selvbekostet omtaksation. Resultatet af denne skulle være bindende. Endelig for det femte foreslog udvalget, 
at det fremover ikke skulle være amtmændene som hidtil, der indgav udtalelse om behovet for nye møllekoncessioner i et bestemt område. I stedet skulle der nedsættes en »bestandig kommission af 3 sagkyndige mænd « til at rådgive regeringen om behovet for nye mølleanlæg. Dette punkt var det mest kontroversielle, idet der hermed ville åbnes op for en vid indflydelse til møllerne i spørgsmål om udstedelse af møllekoncessioner. Samtlige udvalgets hovedpunkter nedstemtes af stænderforsamlingen, ligesom også den kongelige kommissarius - regeringens repræsentant $\mathrm{i}$ forsamlingen - afviste de fremsatte ønsker. Et par mere moderate forslag gik igennem. Alt i alt var forsamlingens endelige udtalelse en bekræftelse af forordningen om mølletvangens ophævelse, som regeringen havde fremlagt den. Følgen af stændernes drøftelser blev, at regeringen 10. februar 1854 genudstedte forordningen af 21. november 1852 med en enkelt, mere kosmetisk, ændring. Lovens behandling i stænderforsamlingen var afgjort et nederlag for mølleejerne.

Den slesvigske stænderforsamling var ikke det eneste politiske organ, der kom til at beskæftige sig med ophævelsen af mølletvangen. Også i helstatsmonarkiets rigsråd kom sagen på dagsordenen. Den 2. oktober 1855 udstedtes, med baggrund i løfter til de europæiske stormagter, en fællesforfatning for hele det danske monarki. To uger efter oprettedes et ministerium for Monarkiets Fælles indre Anliggender, der nærmest var et indenrigsministerium for helstaten. Et delvis folkevalgt rigsråd med repræsentanter for hertugdømmerne og kongeriget skulle efter forfatningen behandle lovgivning om forhold, som var fælles for hele monarkiet. Til dette område hørte finansieringen af mølletvangens ophævelse. Med forfatningen opdeltes statens indtægter og udgifter formelt i to hovedgrupper: De som var fælles for monarkiet, og de som var særlig knyttet til enkelte landsdele. Et udtryk som »den kongelige kasse « fra forordningen om mølletvangens ophævelse gav ikke længere mening. Hidtil var udgifterne til udbetaling af godtgørelse til de tidligere tvangsmøllere blevet hentet i statskassen, dvs. fra de fælles indtægter. Sådan skulle det også være efter udstedelsen af fællesforfatningen. Blot krævede udredelsen nu - som et fællesanliggende - rigsrådets samtykke. Ved udarbejdelsen af forordningen af 21. november 1852 havde Finansministeriet anslået de samlede omkostninger for statskassen ved gennemførelse af reformen til 422.250 rd. cour. ${ }^{64}$ Det beløb viste sig at være utilstrækkeligt. I foråret 1856 måtte regeringen derfor bede rigsrådet om yderligere 
midler. Dette blev ved lov bevilget op til en grænse på 215.000 rd. Der manglede på daværende tidspunkt at blive sluttet overenskomst med omkring 30 tidligere tvangsmøllere i hertugdømmet. Loven medførte en usikkerhed omkring udbetalingen af godtgørelse til de resterende møllere. Ministeriet for Monarkiets Fælles indre Anliggender og Finansministeriet indtog nemlig det standpunkt, at ingen udbetalinger kunne finde sted, før man kendte størrelsen på det samlede erstatningsbeløb for alle tilbageværende tvangsmøllesager i hertugdømmet. Indtil da kunne man ikke vide, om de 215.000 rd. ville slå til, hvorved man risikerede at forfordele de møllere, som fik afsluttet deres erstatningssager til sidst. Ministeriet for Hertugdømmet Slesvig argumenterede omvendt for en løbende udbetaling af godtgørelsessummerne uden skelen til de $215.000 \mathrm{rd}$. Det var dog klart de mere helstatsorienterede ministerier, der havde overtaget på dette tidspunkt. På den baggrund sattes alle udbetalinger af godtgørelse i bero. Det ramte bl.a. mølleren på Jyndevad Mølle i Tønder Amt. Også han havde tøvet med at indgive sin erklæring om kompensation for mølletvangens ophævelse. April 1856 havde han dog oplyst herredsfogderiet, at han ønskede at tage imod regeringens tilbud. Alligevel kunne han et halvt år efter meddele regeringen, at der fortsat intet afdrag var sket i den canon, han blev opkrævet. Nu var han kommet økonomisk i klemme på grund af fastfrysningen af udbetalinger: »Da om juletiderne [...] denne canon er forfalden, og jeg må frygte for da atter at blive krævet for hele beløbet, så skulle jeg underdanigst tillade mig ved nærværende at henlede det kongelige ministeriums opmærksomhed på [...] berørte misligheder. ${ }^{65}$ Først da det med en resolution i november 1856 blev bestemt, at udgifter ud over de $215.000 \mathrm{rd}$. skulle tages fra hertugdømmets særlige indtægter, åbnedes der igen op for udbetalinger. ${ }^{66}$ Sagen illustrerede med al ønskelig tydelighed, at Ministeriet for Hertugdømmet Slesvig var underordnet de to andre, mere helstatsprægede, ministerier. I praksis fik det dog ikke den store betydning for de forhenværende tvangsmøllere.

\section{Sammenfatning}

Ophævelsen af mølletvang i hertugdømmet Slesvig havde tre trin: Taksation af samtlige tvangsmøller, indhentning af erklæringer fra møllerne og endelig udbetaling af godtgørelse. Første trin forløb stort set efter regeringens drejebog. Gennemførelsen af andet trin blev 
mere problematisk. Det skyldtes især møllernes individuelle modstand mod forordningens bestemmelser. Også med fuldførelsen af tredje trin kom det til vanskeligheder. Ikke alene forsinkedes udbetalingen af godtgørelse til møllerne af det langsomme tempo, hvori erklæringerne blev indgivet. Også uenighed mellem flere centrale ministerier om udbetalingsspørgsmålet bragte uorden.

Møllernes svar på de afkrævede erklæringer var i reglen ukoordinerede. Som man i enevældens tid havde henvendt sig til kongen med bønskrifter, gik man nu til Ministeriet for Hertugdømmet Slesvig med ansøgninger om forskellige udvidelser til det gjorte tilbud om økonomisk kompensation. ${ }^{67}$ Kun ved møller Boysens henvendelse til ministeriet på vegne af 48 møllere i hertugdømmet og i den slesvigske stænderforsamlings udvalgsbetænkning kan man tale om en forenet indsats af tvangsmølleindehaverne efter forordningens udstedelse. I det samlede billede gjorde det ingen forskel, om møllernes handlinger var koordineret eller foregik individuelt, idet henvendelserne i reglen blev afvist af regeringen uanset hvad.

Ved ophævelsen af mølletvangen i hertugdømmet blev der ikke taget stort hensyn til indehaverne af tvangsmøller. Det lå dog i den liberale tidsånd, at afskaffelsen af velerhvervede rettigheder skulle kompenseres. ${ }^{68}$ Ganske vist gav forordningen om mølletvangens afskaffelse møllerne to alternativer til modtagelsen af godtgørelsen: Tilbagegivelse af mølleprivilegiet eller sagsanlæg. For hovedparten af de tidligere tvangsmøllere var ingen af disse alternativer imidlertid tillokkende. Mange så ikke andre udveje end at acceptere regeringens tilbud.

Der fandtes tvangsmøllere, som profiterede af mølletvangens afskaffelse. Det gjaldt i første række de, der, som besidderen af Havnbjerg Mølle, blev spået en tilgang i antallet af møllegæster efter tvangsrettens ophævelse. Oprettelsen af nye møller i landskabet kunne imidlertid hurtigt annullere denne fordel. Mere var der trods alt ikke ændret efter mølletvangens afskaffelse.

\section{FORKORTELSER}

RA: Rigsarkivet

MHS: Ministeriet for Hertugdømmet Slesvig 


\section{KILDER}

Utrykte kilder:

RA, 1849-1864 møllesager. Ærø Amt Haderslev Amt.

RA, MHS 2. Departement, 2. Kontor: Møllesager (1849-1864) 2: 1851 Dalby Mølle - 1863 Haderslev Amt mm RA, MHS: Ophævelse af mølletvang (1852-1863) 3: Sønderborg Amt 115 D III - Nordborg Amt 115 D III mm.

RA, MHS: Ophævelse af mølletvang (1852-1863) 2: Haderslev Amt 115 B III.

RA, MHS 1852-1863. Ophævelse af Mølletvang. Aabenraa Amt.

RA, Møllesager 1850-1864. Østergaard Vandmølle 1851-1856 m.m.

\section{LITTERATUR}

Clausen, Thomas (2013): »Kampen om tvangsmølleriets afskaffelse $i$ hertugdømmet Slesvig 1836-1852 «, Sønderjyske Årbøger, s. 7-30.

Cohn, Einar (1967): Økonomi og Politik $i$ Danmark 1848-1875, Gads Forlag.

Danker-Carstensen, Peter (2006): Gewerbeentwicklung und Industrialisierung, Stadt Elmshorn.

Gregersen, H.V. (1970): Laurids Skaus brevveksling med politiske venner i Sønderjylland, Historisk Samfund for Sønderjylland.

Hjelholt, Holger (1925): »Den slesvigske stænderforsamling i 1860», Historisk

\section{NOTER}

1. Tvangsmøller $=$ En møller som var $\mathrm{i}$ besiddelse af en mølle med mølletvangsret. Artiklen er til dels en fortsættelse af forfatterens artikel i Sønderjyske Årbøger 2013.

2. Provisorisk $=$ foreløbig, udstedt inden den slesvigske stænderforsamling kunne udtale sig om loven. Forordningen findes optrykt i St. Tid. 1853-54, Anhang, I. Afdeling, sp. 1518.
Trykte kilder:

Juridisk Ugeskrift for Hertugdømmet Slesvig 1856.

Konge Frederik den sjettes allernaadigste Forordninger og aabne Breve for Aar 1811, København.

Love m.m. for Slesvig 1853.

Rigsraadstidende 1856.

Tidende for Forhandlingerne ved den syvende Provindsialstænderforsamling for Hertugdømmet Slesvig (St. Tid. 1853-54 og St. Tid. 1856-57).

Tidsskrift, Bind 9. række, 3, s. 209-344.

Linow, Hans og Jens Lampe (1966): Møller på Als, Forlaget Faklen.

Madsen, Lennart S. (2011): »Møllerier « i Sønderjylland $A-\dot{A}$, Historisk Samfund for Sønderjylland.

Nielsen, Leif Hansen (2007): Ad Industriens Vej, Historisk Samfund for Sønderjylland.

Plesner, Johan (1925): »Partidannelsen i de slesvigske Provinsialstænder i Tiden mellem de to dansk-tyske Krige«, Sønderjyske Årbøger, s. 225-281.

Uldall, Michael (2007): Tørnings historie, eget forlag.

3. Begrebet »tvangspligtig « brugtes i samtiden om de korntyper og de møllegæster, som var underlagt mølletvangen.

4. Der var således ikke tale om, at møllenæringen efter 1852 blev »et fuldstændigt frit erhverv", som anført hos Nielsen 2007, s. 102. Det er desuden en udbredt misforståelse i den eksisterende forskningslitteratur, at mølletvangen blev afskaffet i 1854, (se f.eks. Uldall 2007, s. 95; Danker-Carstensen 
2006, s. 68), eller sågar i 1862 (se Linow og Lampe 1966, s. 33). Februar 1854 genudstedtes forordningen om mølletvangens afskaffelse efter stændernes rådslagning som en formel akt. 1862 var året, hvor møllenæringen frigaves endeligt $i$ kongeriget efter en overgangstid på 10 år, jf. Cohn 1967.

5. Sagsakterne til mølletvangens ophævelse ligger dels ordnet $i$ tre arkivpakker om mølletvangens ophævelse, dels spredt i forskellige pakker med møllesager for hertugdømmet. Arkivalierne til mølletvangens ophævelse i Tønder og Løgumkloster Amter ligger i pakken mærket Sønderborg og Nordborg. Ministeriet for Hertugdømmet Slesvig oprettedes i marts 1851 efter Treårskrigens afslutning.

6. Jf. regeringens motiver til loven i den slesvigske stænderforsamling: St. Tid. 1853-54, Anhang, I. Afdeling, sp. 19-28.

7. Se herom: Clausen 2013, s. 16-17.

8. Mølletvangen afskaffedes i hertugdømmet Holsten ved lov af 10. maj 1854 med virkning fra 1 . juli 1855 .

9. Om mølletvangen frem til 1852 , se Clausen 2013.

10. Skønt langt hovedparten af tvangsmøllere var mænd, talte gruppen også en del kvinder. Typisk var de enker efter den tidligere mølleejer. Kvinderne var dog formelt set umyndige, hvorfor forhandlingerne om erstatning for mølletvangens afskaffelse som oftest varetoges af en mandlig ægtefælle, slægtning e.l.

11. Se f.eks. en sag herom i Juridisk Ugeskrift for Hertugdømmet Slesvig (1856), s. $393 \mathrm{f}$

12. RA, Ophævelse af mølletvang (18521863) 3: Sønderborg Amt 115 D III Nordborg Amt 115 D III mm. Herefter: RA, mølletvang Sønderborg/ Nordborg; RA, Ministeriet for Hertugdømmet Slesvig: Ophævelse af mølletvang (1852-1863) 1: Aabenraa Amt 115 A II. Herefter: RA, mølletvang Aabenraa.

13. Rigsraadstidende 1856, Anhang A: sp. 1127. Antallet, som er højere end normalt antaget (jf. f.eks. Madsen 2011), understøttes af tabelliste i RA, mølletvang Sønderborg/Nordborg.

14. St. Tid. 1853-54, Anhang, I. Afdeling, sp. 22-23.

15. Det gjaldt bl.a. Emmelsbül Mølle og møllen i Wyck på øen Før under Tønder Amt.

16. RA, MHS 2. Departement, 2. Kontor: Møllesager (1849-1864) 2: 1851 Dalby Mølle - 1863 Haderslev Amt mm. Notat fra Finansministeriet af 12.7. 1854. Herefter: RA, møllesager Dalby Mølle. Tre tvangsmøller på Sylt, Østerhusum Mølle i Husum Amt samt to møller i Garding takseredes ikke.

17. Taksationsrapporter i RA, mølletvang Sønderborg/Nordborg.

18. RA, mølletvang Sønderborg/Nordborg, taksationsrapport for Asserballe Mølle.

19. RA, Mølletvang Aabenraa Amt, taksationsrapport for Hellevad Mølle.

20. RA, møllesager Ærø/Haderslev, møller Petersen til MHS.

21. Dette og det følgende, jf. datering af taksationsrapporterne i RA, MHS 2. Departement, 2. Kontor: Møllesager (1849-1864) 1: 1849 Ærø Amt - 1864 Haderslev Amt. Herefter: RA, møllesager Ærø/Haderslev; RA, mølletvang Sønderborg/Nordborg; RA, Ophævelse af mølletvang (18521863) 2: Haderslev Amt 115 B III. Herefter: RA, mølletvang Haderslev; RA, mølletvang Aabenraa.

22. »Forordning, angaaende bestandige Taksationsmænds udnævnelse, for Hertugdømmerne Slesvig og Holsten « i Konge Frederik den sjettes ..., s. 310-314.

23. RA, mølletvang Sønderborg/Nordborg, taksationsrapport for Havnbjerg Mølle.

24. RA, møllesager Ærø/Haderslev, Chr. Jørgensen til MHS august 1853.

25. En »sandemand « var en form for nævning.

26. Det følgende bygger på taksationsrapporten for Rundemølle i RA, mølletvang Aabenraa.

27. Rigsdaler cour. (courant) var hovedmøntfoden i hertugdømmerne. Den eksisterede ved siden af monarkiets officielle møntfod siden 1813: Rigs- 
bankdaleren. 1854 indførtes en ny møntfod, rigsdaleren, som fælles valuta i helstaten.

28. St. Tid. 1856-57, s. 803.

29. Korrekt: $»$ Akkviescere $«=$ At affinde sig med/indvilge i.

30. RA, møllesager Dalby Mølle, MHS til amtmanden i Haderslev 30.4. 1853.

31. Rapporterne varierer i omfang og detaljerigdom. Nogle fylder en enkelt side, andre 7-8 sider. Standard er omkring 4 sider.

32. RA, møllesager Dalby Mølle, taksationsrapport for Tørning Mølle.

33. Således ministeriets standardformulering i skrivelser til amtmændene.

34. RA, mølletvang Sønderborg/Nordborg, MHS til amtmand grev Reventlow 5.4.1856.

35. På Ærø således f.eks. på fem ud af syv tvangsmøller. Denne fordeling synes at have været repræsentativ for hele hertugdømmet.

36. Dette og det følgende baserer sig på taksationsrapporterne.

37. RA, Sønderborg/Nordborg, møller Gorrisen til MHS 4.4.1857.

38. Sammentælling på baggrund af tabellister, jf. note 12 .

39. RA, mølletvang Haderslev, møller Ravn på Ultang Mølle til MHS 26.2.1857.

40. RA, mølletvang Sønderborg/Nordborg, møller Matzen til MHS.

41. RA, Sønderborg/Nordborg, møller Gorrisen til MHS 4.4.1857.

42. RA, møllesager Ærø/Haderslev, møller Petersen til MHS.

43. RA, mølletvang Sønderborg/Nordborg, møller Voss til MHS maj 1854.

44. Det har således under arkivarbejdet ikke været muligt at finde én ansøgning, hvor det efterspurgte bevilgedes. Kun ansøgninger om betænkningstid blev i nogen udstrækning imødekommet.

45. Samme som note 12 .

46. De otte møller var: Husby Mølle i Flensborg Amt, Gottorp Mølle og Hessel Mølle i Gottorp Amt, Stenten Mølle i Hütten Amt, Drelsdorf Mølle i Bredsted Amt, Crode (?) Mølle i landskabet Stabelholm samt Nybøl Mølle og Læk Mølle i Tønder Amt. Jf. tabellister i RA, mølletvang Sønderborg/Nordborg.

47. Mageskifte $=$ "Erhvervelse af en urørlig ting (fast ejendom) mod en anden urørlig ting som helt ell. delvist vederlag « (definition hentet på ordnet.dk).

48. RA, mølletvang Sønderborg/Nordborg, koncept af MHS's svar til amtmanden i Tønder.

49. RA, møllesager Ærø/Haderslev.

50. Der henvises i almindelighed til diskussionen om sagen vedr. møller Beeck i Krusaa i St. Tid. 1856-57.

51. RA, mølletvang Sønderborg/Nordborg, møller Jacobsen til amthuset i Sønderborg.

52. Ifølge et udateret notat fra MHS (sandsynligvis december 1856) havde samlet set omkring 25 møllere ultimo 1856 erklæret at ville gå rettens vej. Listen synes dog ikke at være udtømmende, da eksempelvis Vibæk Mølle og Brenduhr Mølle ikke er medtaget. RA, Dalby Mølle.

53. RA, mølletvang Haderslev, oversagfører Schmidt v. Leda til MHS 6.3. 1857.

54. RA, møllesager Ærø/Haderslev, v. Leda til MHS februar 1857.

55. Arkivalierne til belysning af denne sag er hentet i RA, mølletvang Haderslev.

56. RA, mølletvang Haderslev. 48 indehavere af tvangsmøller til MHS.

57. RA, Møllesager 1850-1864. Østergaard Vandmølle 1851-1856 m.m.; Gregersen 1970, s. 374.

58. RA, mølletvang Haderslev, advokat Salicath til MHS 4.3.1857.

59. Mølletrang = Det forhold, at der i et område var for få møller i forhold til efterspørgslen på maleydelser.

60. Om Blixen-Fineckes rejse til hertugdømmet Slesvig se Hjelholt (1925).

61. St. Tid. 1853-54, Anhang II: sp. 65.

62. Plesner 1925, s. 237.

63. Betænkningen findes i St. Tid. 185354, Anhang II: sp. 65-76.

64. RA, Dalby Mølle, notat fra Finansministeriet af 12.7.1854.

65. RA, mølletvang Sønderborg/Nordborg, møller Heinrich Voss til MHS 30.10.1856.

66. RA, mølletvang Sønderborg/Nord- 
borg, Ministeriet for Monarkiets Fælles indre Anliggender til MHS 19.12. 1856.

67. Betegnende er det, at mølleren i Marstal indleder sin ansøgning til ministeriet med ordene »til Kongen!«. RA, møllesager Ærø/Haderslev, møller Petersen til MHS.
68. Jf. Orla Lehmanns ytring under rigsrådets debat om mølletvangens ophævelse: »Der gaves Tider, hvor disse [tvangsmøllerne] takkede Gud, naar de kunne slippe med at miste Rettighederne og beholde Livet «. Rigsraadstidende 1856: sp. 1465.

\section{Zusammenfassung}

Die Aufhebung des Mühlenzwanges im Herzogtum Schleswig fand in drei Stufen statt: Schätzung sämtlicher Zwangsmühlen, Einholen von Erklärungen von den Mühlen und schließlich Auszahlung der Vergütung. Die erste Stufe verlief meistens laut Drehbuch der Regierung. Die Durchführung der zweiten Stufe konnte problematisch sein, hauptsächlich wegen des individuellen Widerstandes bei den Müllern gegen die verordneten Bestimmungen. Auch die Durchführung der dritten Stufe stieß auf Schwierigkeiten. Die Vergütung wurde oft durch das langsame Tempo bei Eingabe der Erklärungen verspätet. Auch Auseinandersetzungen zwischen verschiedenen Ministerien über Fragen der Auszahlung machten Probleme.

Die Antworten der Müller auf die verlangten Erklärungen waren in der Regel nicht koordiniert. In den Zeiten des Absolutismus hatte man sich mit Fürbitten an den König gewendet, jetzt richtete man seine Anfragen an das Ministerium für das Herzogtum Schleswig mit Anträgen auf verschiedenartige Erweiterungen zum Angebot an finanzieller Gutmachung. Das Ministerium lehnte solche Anmutungen $\mathrm{ab}$.

Bei Aufhebung des Mühlenzwanges im Herzogtum wurden die Inhaber der Zwangsmühlen nicht besonders berücksichtigt. Der liberale Zeitgeist bedeutete jedoch, dass das Abschaffen erworbener Rechte kompensiert werden musste. Die Verordnungen zum Abschaffen des Mühlenzwanges gab den Müllern zwei alternative Möglichkeiten für den Empfang von Vergütung: Zurückgabe des Mühlenprivilegs oder gerichtliche Klage.

Nur für die wenigsten der früheren Zwangsmüller waren diese Alternativen verlockend. Für viele gab es nur den Ausweg der Annahme des Regierungsangebots. 